\title{
Immediate and long term effects of a cosmetic formulation with Cichorium intybus root extract
}

\author{
Efeitos imediatos e em longo prazode uma formulação cosmética contendo extrato da raiz de \\ Cichorium intybus
}

Thaís R. Paseto, Tais A. L. Wagemaker, Patrícia M. B. G. Maia Campos

University of São Paulo, School ofPharmaceuticalSciencesof Ribeirão Preto, Brazil

Email: pmcampos@usp.br

\begin{abstract}
Dry skin is characterized as a rough and scaling skin surface. It usually has lower water content than normal skin. Vitamin D helps to regulate cellular proliferation and differentiation andcan help to protect skin from environmental factors. However, the stability vitamin D in cosmetic formulations is low. Thus, the aim of this study was to evaluate the sensory properties and protective effects on skin hydration of a cosmetic formulation containing Cichorium intybus root extract, previously shown to be "vitamin D like" (VD). A formulation containing VD or not (vehicle) was applied on the arm, forearm and face of fifteen subjects. Measurements of stratum corneum water content, Transepidermal Water Loss (TEWL) and skin microrelief parameters were performed using biophysical and skin image techniques before (baseline), after 2 hours, and after 45 and 90 days of daily application of the formulations. Only the formulation with VD was effective in maintaining skin barrier function and skin hydration under low humidity conditions. Cichorium intybus root extract is shown to be an effective "vitamin D like" active ingredient to use in cosmetic formulations to avoid skin dryness. In addition, the extract maintained the sensory properties of the studied cosmetic formulation.
\end{abstract}

Keywords: Cichorium intybus root extract, "Vitamin D-like", cosmetics, biophysical techniques, skin dryness, sensory properties

\section{Resumo}

A pele seca é caracterizada como uma superfície áspera, com menor teor de água do que a pele normal. A Vitamina $\mathrm{D}$ ajuda a regular a proliferação e diferenciação celular e pode ajudar a proteger a pele contra fatores ambientais. No entanto, a Vitamina D é instável em formulações cosméticas. Assim, o objetivo deste estudo foi avaliar o sensorial e os efeitos protetores na hidratação da pele de uma formulação cosmética contendo extracto de raiz Cichorium intybus - "Vitamina D like" (VD). A formulação, adicionada ou não (veículo) de VD, foi aplicada no braço, antebraço e na face de quinze participantes. Antes (basal) e após 2 horas, 45 e 90 dias de aplicação diária das formulações foram realizadas medidas do conteúdo aquoso do estrato córneo, perda de água transepidémica e parâmetros do microrrelevo da pele por técnicas biofísicas e análise de imagem. Apenas a formulação com VD foi efetiva na manutenção da função barreira e hidratação da pele em condições de baixa umidade. Assim, oextracto de raíz de Cichorium intybus é um ingrediente ativo eficaz para aplicação em cosméticos para evitar o ressecamento da pele. Além disso, a "Vitamina D like" melhorou o sensorial da formulação cosmética estudada.

Palavras chave: extracto de raiz de Cichorium intybus, "Vitamina D-like", cosméticos, técnicas de biofísica, pele seca, propriedades sensoriais. 


\section{Introduction}

Dry skin (xerosis) is characterized as a rough and finely scaling skin surface. This conditionis generally associated with lower water content than normal skin.Dry skin is a common skin condition in the winter. It becomes worse by environmental factors, such as cold and dry weather ${ }^{(1)}$.

Low humidity in winter creates an ideal condition for dry skin. The stratum corneum becomes more vulnerable to cracking, resulting in skin barrier breakdown. Thus, low humidity may damage the barrier causing skin irritation, redness and itching ${ }^{(2)}$.

Vitamin D and/or its receptor regulate numerous functions of the skin. These include inhibition of proliferation and stimulation of cell differentiation ${ }^{(3)}$. According to Bikle ${ }^{(4)}$, vitamin D regulates formation of the permeability barrier, promotion of innate immunity, and promotion of the hair follicle cycle.

Loss of vitamin D receptor or loss of the capacity to produce $1,25(\mathrm{OH})_{2} \mathrm{D} 3$ (1,25-dihydroxycholecalciferol or calciferol) disrupts differentiation of the epidermis and resultsinhyperproliferation of the basal layers ${ }^{(5)}$.

Russel $^{(5)}$ demonstrated a relationship between vitamin $\mathrm{D}_{3}(25(\mathrm{OH}) \mathrm{D}$ - calcifediol) serum levels and the skin hydration state. This author concluded that if thevita$\operatorname{minD}_{3}$ serum level decreases, skin conductance measurements also decrease, indicating that skin is drier. In addition, synthesis of vitamin $\mathrm{D}$ and its receptor in the skin decrease with reduced sun exposure and ageing. Thus, the use of cosmetics products with vitamin D may help improve skin conditions ${ }^{(6)}$.Another study showed that mice lacking vitamin $\mathrm{D}$ receptors showed defective epidermal differentiation, manifested asreduced levels of involucrinandloricrin and loss of keratohyaline granules ${ }^{(7)}$.

Considering that vitamin $\mathrm{D}$ regulates important skin mechanisms but it has a low stability in cosmetic formulations $^{(8)}$, a new active ingredient obtained from Cichorium intybus (common chicory) root extract was proposed to act on the skin as vitamin D.

Cichorium intybus root extract - "vitamin D like" -is rich in oligofructosans, which stimulates vitamin D receptor synthesis. The receptor binds to vitamin D response elements by specific DNA sequences inthe nucleus. This binding affects the transcription of target genes that regulate cellular proliferation and differentiation $^{(9)}$. In addition, the clinical efficacy of this active ingredient in the improvement of skin barrier function has been demonstrated by Maia Campos et $\mathrm{al}^{(6)}$.

In this context, the aim of this study was to evaluate the sensory properties and protective effects on skin hydra-

\section{Introdução}

A pele seca (xerosis) é caracterizada como uma superfície de pele áspera e finamente descamante. Geralmente tem menor teor de água do que a pele normal. A pele seca é uma condição comum da pele no inverno. Torna-se pior devido às condições climáticas, como clima frio e seco ${ }^{(1)}$.

A baixa umidade no inverno torna as condições ideais para a pele seca. O estrato córneo torna-se mais vulnerável a rachaduras que resultam na ruptura da barreira da pele. Desta forma, a baixa umidade pode danificar a barreira causando irritação na pele, eritema e coceira ${ }^{(2)}$. A Vitamina D e/ou o seu receptor regulam numerosas funções da pele. Estas incluem a inibição da proliferação e estimulação da diferenciação celular ${ }^{(3)}$. De acordo com Bikle ${ }^{(4)}$, a Vitamina D regula a formação da barreira de permeabilidade, a promoção da imunidade inata e a promoção do ciclo do folículo capilar.

A perda de receptor de Vitamina D ou perda da capacidade de produzir 1,25(OH)2D (diidroxicolecalciferol ou calciferol) interrompe a diferenciação da epiderme e resulta em hiperproliferação das camadas basais ${ }^{(5)}$.

Russel $^{(5)}$ demonstrou uma relação entre os níveis séricos de Vitamina D3 (25(OH)D- calcifediol) e o estado de hidratação da pele. Este autor concluiu que, se o nível sérico da Vitamina D3 diminuir, as medidas de condutância da pele também diminuiríam, indicando que a pele estava mais seca. Além disso, a síntese de Vitamina D e de seu receptor diminui com a redução da exposição ao sol e com o envelhecimento. Assim, o uso de produtos cosméticos com Vitamina D pode ajudar a melhorar as condições da pele ${ }^{(6)}$. Outro estudo mostrou que ratos que não possuem receptores de Vitamina $\mathrm{D}$ apresentam diferenciação epidérmica defeituosa que se manifesta como níveis reduzidos de involucrina e loricrina e perda de grânulos de querato-hialina ${ }^{(7)}$.

Considerando que a Vitamina D regula os mecanismos importantes da pele, mas possui baixa estabilidade nas formulações cosméticas ${ }^{(8)}$, um novo ingrediente ativo obtido a partir do extracto da raiz de Cichorium intybus foi proposto para atuar sobre a pele como a Vitamina D. O extracto de raíz de Cichorium intybus - "Vitamina D Like" é rico em oligofructosanas, o que estimula a síntese do receptor de Vitamina D. O receptor se liga a elementos de resposta de Vitamina D por seqüências de DNA específicas no núcleo. Estaligaçãoafeta a transcrição de genes alvo que regulam a proliferação e diferenciação celular ${ }^{(9)}$. Além disso, Maia Campos e colaboradores ${ }^{(6)}$ demonstraram a eficácia clínica deste ingrediente ativo na melhoria da função barreira da pele. Nesse contexto, o objetivo deste estudo foi avaliar as 
tion of a cosmetic formulation containing Cichorium intybus root extract, referred herein as "vitamin D like" (VD).

\section{Material and methods}

\section{Studied Formulation}

The formulation under study was composed of deionized water, butyleneglicol (Butilenoglicol, Mapric, Brazil), glycerin PA (Glicerina, Mapric, Brazil), ethylhexyl stearate (Crodamol OS ${ }^{\circledR}$, Croda International Plc, United Kingdom), aqua and PEG-75 lanolin (Solangel $401^{\circledR}$, Croda International Plc, United Kingdom), sodium polyacrilate, dimethicone, and cyclopentasil (RM $2051^{\circledR}$, Dow Corning, USA), cyclopentasiloxane (Xiameter $^{\circledR}$ PMX-0245 Cyclopentasiloxane, Dow Corning, USA), phenoxyethanol, methylparaben, ethylparaben, butylparaben, propylparaben and isobutylparaben (Phenova ${ }^{\circledR}$, Croda International Plc, United Kingdom), disodium EDTA (EDTA Dissódico, Mapric, Brazil), acrylates/ C10-30 alkyl acrylate crosspolymer (Pemulen ${ }^{\mathrm{TM}}$ TR-2 NF Polymer, Lubrizol, USA), to which was added or not (vehicle) Cichorium intybus(common chicory) root extract (Vederine ${ }^{\circledR}$, Silab, France) to a final concentration of $3 \%$.

\section{Subjects}

This study was approved by the Ethics Committee of the School of Pharmaceutical Sciences of Ribeirão Preto USP(CEP/FCFRP 381 - CAEE 43463115.0.0000.5403) and conformed to the principles set forth by the Declaration of Helsinki. For the efficacy assessment, fifteen healthy female subjects, 18 - 39 years old, with Fitzpatrick skin phototypes II and III, participated in this study after have given their informed consent.

For the sensory analysis, forty healthy female subjects, 18 -39 years old, with Fitzpatrick skin phototypes II and III, participated in this study after have given their informed consent.The exclusion criteria was presence of any dermatitis and/or other skin diseases and smokers and previous treatment of the skin of the forearms and face with cosmetic formulations such as moisturizers, sunscreens or anti-ageing cosmetics 12 hours baseline measurements and during all the period of study.

\section{Efficacy assessments}

Prior to all measurements (baseline, after 2 hours, after 45 and 90 days) subjects of study were left in a con- propriedades sensoriais e os efeitos protetores sobre a hidratação da pele de uma formulação cosmética contendo extracto de raíz de Cichorium intybus - "Vitamina D like" (VD).

\section{Material e métodos}

\section{Formulação estudada}

A formulação em estudo foi composta por água deionizada, butilenglicol (Butilenoglicol, Mapric, Brasil), glicerina PA (Glicerina, Mapric, Brasil), estearato de etilhexilo (Crodamol OS ${ }^{\circledR}$, Croda International Plc, Reino Unido), água e PEG-75 lanolina (Solangel401 ${ }^{\circledR}$, Croda International Plc, Reino Unido), poliacrilato de sódio e dimeticona e ciclopentasil (RM 2051 ${ }^{\circledR}$, Dow Corning, EUA), ciclopentasiloxano (XIAMETER ${ }^{\circledR}$ PMX-0245 Cyclopentasiloxane, Dow Corning, EUA), fenoxietanol e metilparabeno e etilparabeno e butilparabeno e propilparabeno e isobutililparabeno (Phenova ${ }^{\circledR}$, Croda International Plc, Reino Unido), EDTA dissódico (EDTA Dissódico, Mapric, Brasil), acrilatos/copolímero de acrilato de alquilo C10-30 (Pemulen TM TR-2 NF Polymer, Lubrizol, EUA), e adicionada ou não (veículo) de $3 \%$ de extracto de Chicória (Vederine ${ }^{\circledR}$, Silab, França).

\section{Participantes}

Este estudo foi aprovadopelo Comitê de Ética da Faculdade de Ciências Farmacêuticas de RibeirãoPreto - USP (CEP/FCFRP 381 - CAEE 43463115.0.0000.5403) conforme os princípios estabelecidos na Declaração de Helsinque. Para os estudos de eficácia, quinze indivíduos do sexo feminino, saudáveis, de 18 a 39 anos, tendo pele Fitzpatrick tipos II e III, participaram deste estudo, depois de terem dado o seu consentimento informado.

Para a análise sensorial, quarenta indivíduos do sexo feminino, saudáveis, de 18 a 39 anos, tendo pele Fitzpatrick tipos II e III, participaram deste estudo, depois de terem dado o seu consentimento informado

Os critérios de exclusão foram: presença de qualquer dermatite e/ou outras doenças da pele ou alérgicas, fumantes e tratamento prévio da pele dos antebraços e do rosto com formulações cosméticas tais como hidratantes, protetores solares ou cosméticos anti- envelhecimento 12 horas antes das medidas basais e durante todo o período de estudo.

\section{Avaliação de eficácia}

Antes de todas as medidas, tempo zero, após 2 horas, 
trolled room for at least 20 minutes in order to allow full skin adaptation to room temperature $\left(20 \pm 2^{\circ} \mathrm{C}\right)$ and humidity (45-60\%). Biophysical and skin image techniques were used in analysis of the skin conditions after application of formulation on the face skin (malar region), volar forearm, and volar arm of the participants of the study.

The forearm skin area $\left(12 \mathrm{~cm}^{2}\right.$ each $)$ of each subject was demarcated in three regions in one forearm. The formulations studied and the measurement regions were randomized. To each demarcated area, the formulation containing Cichorium intybus root extract, or the vehicle, or no formulation (control) was applied. The malar region skin area was demarcated on both sides. The vehicle or the formulation containing Vitamin D like (VD) was applied following a randomized design. The volar arm skin area was marked in both arms. The vehicle or the formulation containing VD was applied following a randomized design.

\section{Effects after a single application (short term efficacy)}

Before (baseline measurements) and after two hours of the application of $20 \mathrm{mg}$ of each formulation (vehicle or the formulation containing Cichorium intybus root extract) on the volar forearm, volar arm and malar region of the face, measurements were performed to evaluateof the stratum corneum water content, Transepidermal Water Loss (TEWL) and skin microrelief parameters.

\section{Effects after 45- and 90- day application periods (long} term efficacy)

Before (pre-treatment measurements) and after 45 and 90 days of daily application of the formulations on the face (vehicle and formulation containing Cichorium intybus root extract), measurements were again performed to evaluate stratum corneum water content, Transepidermal Water Loss (TEWL) and skin microrelief parameters.

\section{Instrumentation}

The stratum corneum water content was determined with a noninvasive skin capacitance meter (CorneometerCK Eletronics GmbH, Koln, Germany). This device determines the water content of superficial epidermal layers down to a depth of around $0.1 \mathrm{~mm}$ and expresses the values obtained in arbitrary units. The averaged values of three measurements were used for subsequent calculations $^{(10)}$.

Transepidermal Water Loss (TEWL) was measured with an evaporimeter (Tewameter ${ }^{\circledR}$ TM 300, CK Eletronics $\mathrm{GmbH}$, Koln, Germany), and registered in $\mathrm{g} / \mathrm{m}^{2} \mathrm{~h}^{(11)}$. após 45 e 90 dias, os participantes do estudo foram deixados em uma sala controlada por pelo menos $20 \mathrm{~min}$ para permitir a adaptação completa da pele à temperatura ambiente $\left(20 \pm 2^{\circ} \mathrm{C}\right)$ e à umidade $(45-60 \%)$. As técnicas de biofísica e de imagem da pele foram utilizadas na análise das condições da pele após a aplicação da formulação na pele da cara (região malar), parte interna do antebraço e do braço dos participantes do estudo.

A área da pele do antebraço $\left(12 \mathrm{~cm}^{2}\right.$ cada $)$ de cada participante foi demarcada em três regiões em um antebraço. As formulações estudadas e as regiões de medição foram randomizadas. Cada área demarcada recebeu o veículo ou a formulação contendo extracto de raiz Chicória ou nenhuma formulação foi aplicada (controle). A área da pele da região malar foi demarcada em ambos os lados. O veículo ou a formulação contendo Vitamina D como (VD) foi aplicado seguindo um desenho randomizado. A área da pele interna do braço foi marcada em ambos os braços. O veículo ou a formulação contendo VD foram aplicados seguindo um desenho randomizado.

Efeitos após uma única aplicação (eficácia a curto prazo)

Antes (pré-tratamento) e após duas horas de aplicação de $20 \mathrm{mg}$ de cada formulação (veículo ou a formulação contendo extracto de raiz de chicória) foram feitas medidas do teor de água do estrato córneo, perda transepidermal de água e parâmetros de microrrelevo da pele nas regiões anteriores do antebraço e braço e na região malar da face.

Efeitos após o periodo de aplicação de 45 e 90 dias (eficácia em longo prazo)

Antes (basal) e após 45 e 90 dias de aplicação diária das formulações na região da face, foram realizadas medições em termos de teor de água do estrato córneo, perda transepidermal de água e parâmetros de microrrelevo da pele.

\section{Instrumentação}

O teor de água do estrato córneo foi determinado com um medidor de capacitância da pele não invasivo (Corneometer ${ }^{\circledR}$ TM CM 825, CK EletronicsGmbH, Koln, Alemanha). Este dispositivo determina o teor de água das camadas epidérmicas superficiais até uma profundidade de cerca de $0,1 \mathrm{~mm}$ e expressa os valores obtidos em unidades arbitrárias. Os valores médios de três medidas foram utilizados para cálculos posteriores ${ }^{(10)}$.

A perda de água transepidermalfoi medida com um eva- 
Skin microrelief parameters were evaluated using Visioscan $^{\circledR}$ VC98 and software SELS 2000 from CK Eletronics $\mathrm{GmbH}$ (Koln, Germany). The measuring area was $6 \times 8 \mathrm{~mm}$ and the image of the skin was taken by a built-in CCD camera ${ }^{(10)}$. The SELS (Surface Evaluation of the Living Skin) method is based on a graphic depiction of the living skin under special illumination, and the electronic processing and evaluation of this image was carried out according to four clinical parameters: width of wrinkles- skin smoothness (Sesm), number and width of wrinkles (Sew), skin roughness (Ser) and wrinkle depth $(\mathrm{Rt})^{(12)}$.

\section{Sensory analysis}

All subjects rested in a room maintained at $25 \pm 1^{\circ} \mathrm{C}$ and $40-60 \%$ relative humidity for 15 minutes prior to evaluation. Subjects were instructed to not use moisturizers, body lotions, soap or other occlusive cosmetic preparations on the tested area for 12 hours prior to study. $50 \mu \mathrm{L}$ of the formulation on a delimited area (12 $\mathrm{cm}^{2}$ ) of the internal side of the forearm was applied with one finger, performing 10 rubs.

The subjects evaluated the following attributes during application: spreadability, moisturizing, softness, skinfeel (during the application) and, afterfeel (5 minutes after application). A five-level score, with numbers from 1- "bad" to 5- "excellent" was used to evaluate both formulations ${ }^{(12)}$.

\section{Statistical analysis}

In order to evaluate the normal distribution of the experimental data the normality test KolmogorovSmirnov was used using statistical software Origin 9.0. For short term or long term effects on the volar forearm, data were analyzed using ANOVA parametric analysis with Tukey's post-test. For short term or long term effects on the malar region of the face, and for texture profile, Students T test was used. The above tests were performed using GraphPad Prism 5.0. Differences were accepted as statistically significant at $\mathrm{p}<0.05$.

\section{Results}

\section{Effects after a single application}

After two hours of study the stratum corneum water porímetro (Tewameter ${ }^{\circledR}$ TM 300, CK EletronicsGm$\mathrm{bH}$, Koln, Alemanha) e registrado em $\mathrm{g} / \mathrm{m}^{2} \mathrm{~h}{ }^{(11)}$.

Os parâmetros do microrrelevo da pele foram avaliados usando o Visioscan ${ }^{\circledR}$ VC98 e o software SELS 2000 da CK EletronicsGmbH (Koln, Alemanha). A área de medição foi de $6 \times 8 \mathrm{~mm}$ e a imagem da pele foi tomada por uma câmera CCD embutida ${ }^{(10)}$. O método SELS (Avaliação da superfície da pele viva) baseia-se em uma descrição gráfica da pele sob iluminação especial, e o processamento eletrônico e a avaliação desta imagem foram realizados de acordo com quatro parâmetros clínicos: largura das rugas - Suavidade da pele (Sesm), número e largura das rugas (Sew), rugosidade da pele (Ser) e profundidade das rugas $(\mathrm{Rt})^{(12)}$.

\section{Análise sensorial}

Quarenta mulheres participantes do estudo, entre 18 e 39 anos, foram recrutadas. Todas as participantes descansaram em uma sala mantida a $25 \pm 1^{\circ} \mathrm{C}$ e $40-60 \%$ de umidade relativa durante 15 min antes da avaliação. As participantes foram instruídas a não usar hidratantes, loções para o corpo, sabão ou outras preparações cosméticas oclusivas na área testada durante $12 \mathrm{~h}$ antes do estudo. Foi aplicado $50 \mu \mathrm{L}$ da formulação na área delimitada $\left(12 \mathrm{~cm}^{2}\right)$ na porção anterior do antebraço com um dedo, com 10 esfregas.

As participantes avaliaram os seguintes atributos durante a aplicação: espalhabilidade, hidratação, suavidade, sensação na pele durante a aplicação após 5 minutos de aplicação. Uma nota de cinco níveis, com números de 1- "ruim" para 5 "excelente", foi utilizada para avaliar ambas as formulações ${ }^{(11)}$.

\section{Análise estatística}

A fim de avaliar a distribuição normal dos dados experimentais, o teste de normalidade Kolmogorov-Smirnovfoi utilizado o software estatístico Origin 9.0. Para efeitos de curto ou longo prazo sobre a parte interna do antebraço, os dados foram analisados usando análise paramétrica de ANOVA com pós-teste de Tukey. Para efeitos de curto prazo ou longo prazo na região malar da cara, e para o perfil de textura, utilizou-se o teste de $\mathrm{T}$ de Student. Os testes acima foram realizados usando GraphPad Prism 5.0. As diferenças foram aceitas como estatisticamente significativas com $\mathrm{p}<0,05$.

\section{Resultados}

\section{Efeitos após uma única aplicação}

Após duas horas de estudo, o teor de água do estrato 
content significantly increased for the regions evaluatedexcept control (Figure 1). The application of both formulations significantly reducedthe transepidermal water loss on the forearm of the subjects of study (Figure
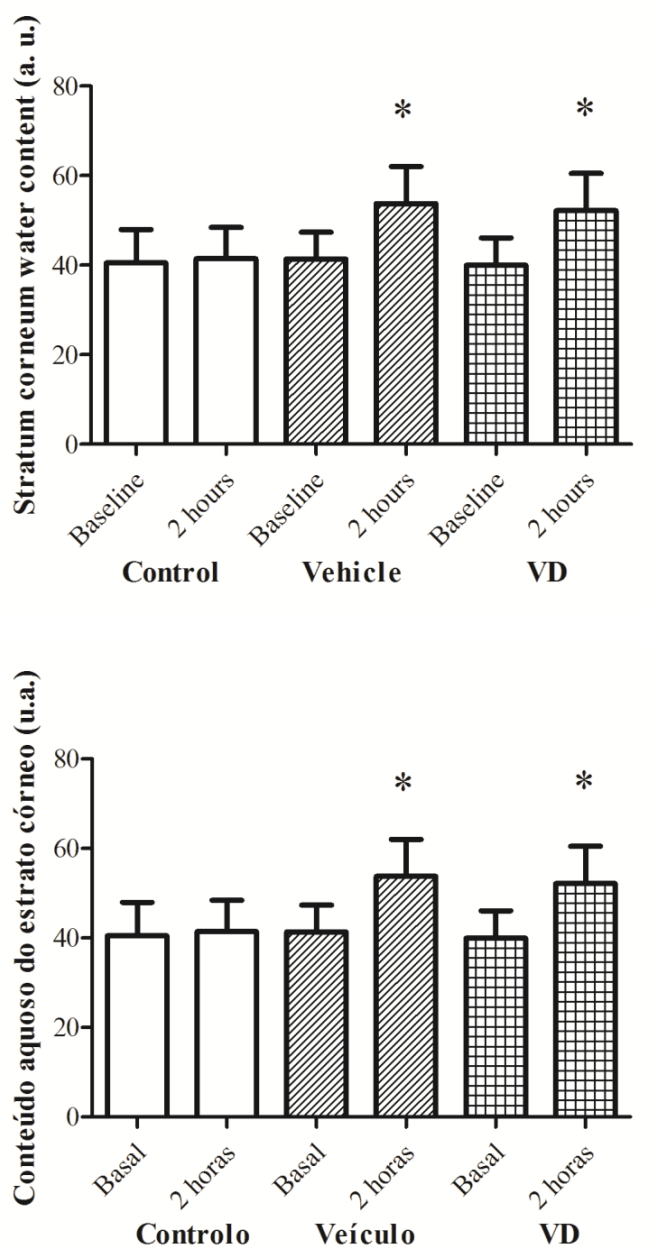

Figure 1/ Figura 1 - Stratum corneum water content (means + SD) for each treatment applied on the volar forearm. Data was obtained by Corneometer measurements after 0 and 2 hours application $(\mathrm{n}=$

15). Control - skin without formulation, Vehicle

- formulation without VD and VD - formulation containing $3 \%$ of Cichorium intybus extract.* Indicates statistically different relative to the baseline $(p \leq 0.05)$.

Conteúdo de água do estrato córneo (média + DP) para cada tratamento aplicado na região interna do antebraço. Os dados foram obtidos por medidas de Corneometer após 0 e 2 horas de aplicação $(n=15)$. Controlo - pele sem formulação, Veículo - formulação sem VD e VD - formulação contendo 3\% de extracto de Cichorium intybus. * Médias estatisticamente diferente comparando com medidas basais e após 2 horas de aplicação $(\mathrm{p} \leq 0,05)$. córneo aumentou significativamente para as regiões avaliadas, exceto o controle (Figura 1). A aplicação de ambas as formulações reduziu significativamente a perda de água transepidermal no antebraço dos participan-
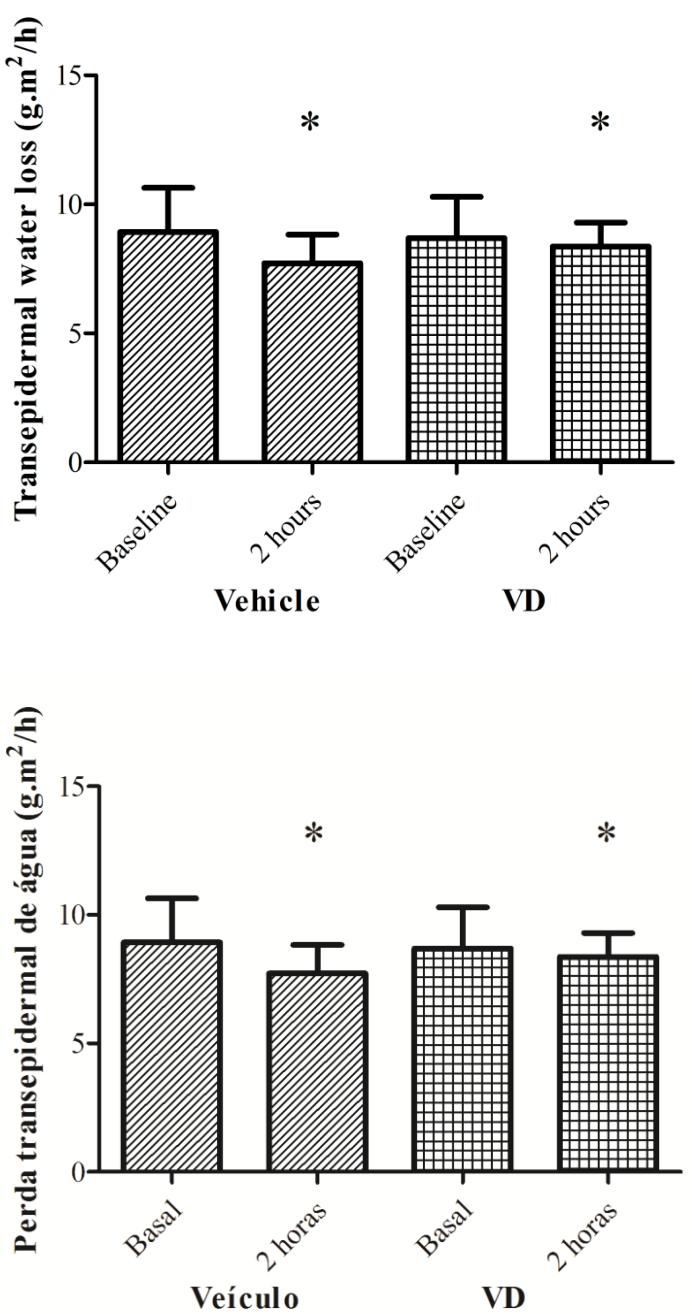

Figure 2/ Figura 2. Transepidermal water loss (means + SD) for each treatment applied on the malar region of the face. Data was obtained by Tewameter measurements after 0 and 2 hours application $(\mathrm{n}=$

15). Control - skin without formulation, Vehicle

- formulation without VD and VD - formulation containing $3 \%$ of Cichorium intybus extract. * Means statistically different comparing baseline and after 2 hours application $(\mathrm{p} \leq 0.05)$.

Perda transepidermal de água (média + DP) para cada tratamento aplicado na região interna do antebraço. Os dados foram obtidos por medidas de Tewameter após 0 e 2 horas de aplicação $(n=15)$. Controlo - pele sem formulação, Veículo - formulação sem VD e VD - formulação contendo 3\% de extracto de Cichorium intybus. * Médias estatisticamente diferente comparando com medidas basais e após 2 horas de aplicação $(\mathrm{p} \leq 0,05)$. 

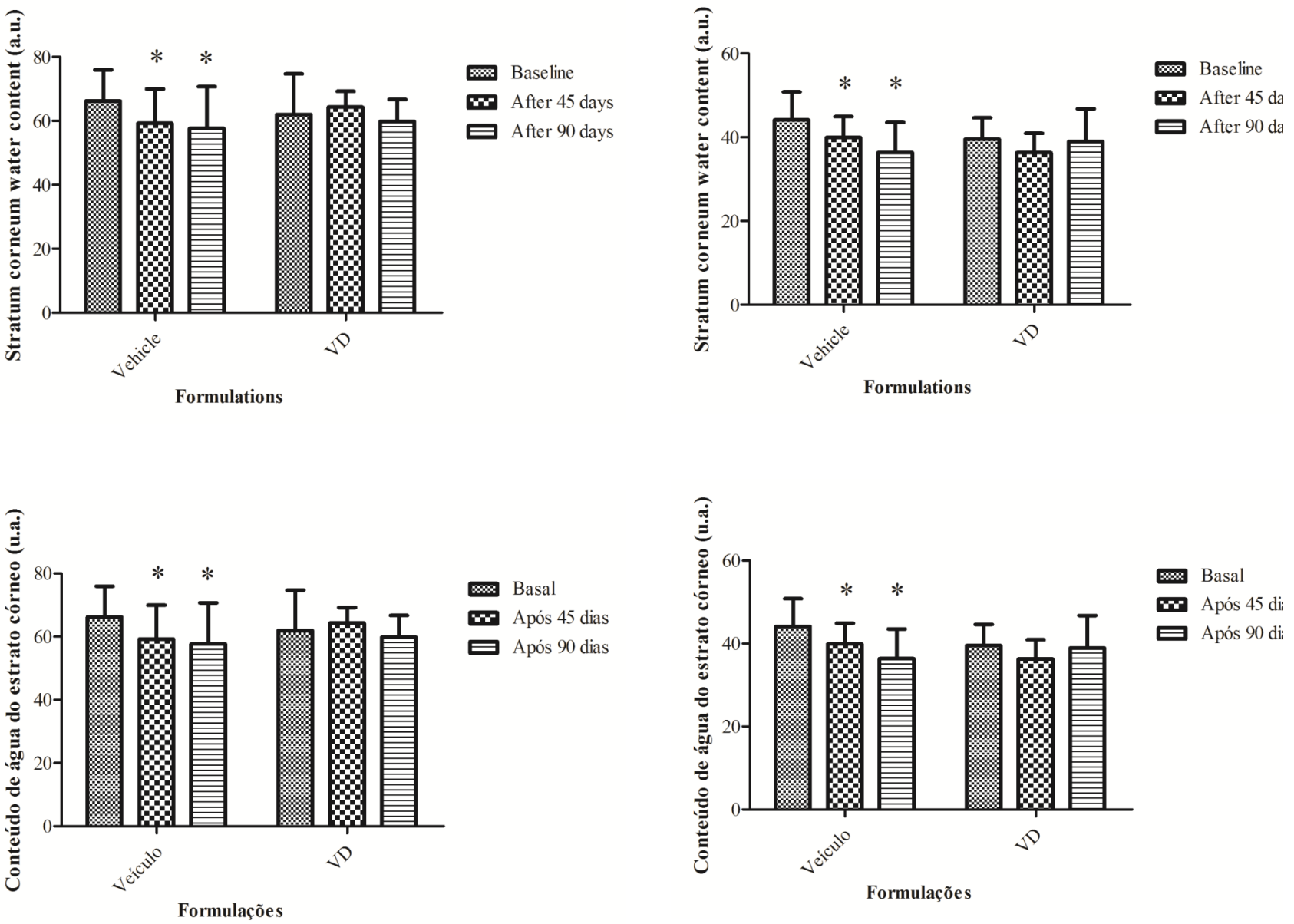

Figure 3/ Figura 3 - Stratum corneum water content (means + SD) for each treatment applied on the malar region of the face. Data was obtained by Corneometer measurements after 0,45 and 90 days of daily application $(\mathrm{n}=15)$. Control - skin without formulation, Vehicle formulation without VD and VD - formulation containing $3 \%$ of Cichorium intybus extract.* Indicatesstatistically different relativeto the baseline $(p \leq 0.05)$.

Conteúdo de água do estrato córneo (média + DP) para cada tratamento aplicado na região malar da cara. Os dados foram obtidos por medidas de Corneometer após 0, 45 e 90dias de aplicação diária $(\mathrm{n}=15)$. Controlo - pele sem formulação, Veículo - formulação sem VD e VD - formulação contendo 3\% de extracto de Cichorium intybus. * Médias estatisticamente diferente comparando com medidas basais e após 2 horas de aplicação $(p \leq 0,05)$.

Figure 4/ Figura 4 - Stratum corneum water content (means + SD) for each treatment applied on the volar forearm. Data was obtained by Corneometer measurements after 0,45 and 90 days of daily application $(n=15)$. Control skin without formulation, Vehicle - formulation without VD and VD - formulation containing $3 \%$ of Cichorium intybus extract. *Indicates statistically different relativeto the baseline $(\mathrm{p} \leq$ 0.05 ).

Conteúdo de água do estrato córneo (média + DP) para cada tratamento aplicado na região interna do antebraço. Os dados foram obtidos por medidas de Corneometer após 0, 45 e 90 dias de aplicação diária $(n=15)$. Controlo - pele sem formulação, Veículo - formulação sem VD e VD - formulação contendo 3\% de extracto de Cichorium intybus. * Médias estatisticamente diferente comparando com medidas basais e após 2 horas de aplicação $(\mathrm{p} \leq 0,05)$. 
2).The other regions and parameters evaluated show no significant differences.

\section{Long term effects}

\section{Stratum corneum water content}

Results of this study showed that the stratum corneum water content of the region treated with the vehicle significantly decreased after 45 and 90 days of applying the formulations. Meanwhile the region treated with the formulation containing Cichorium intybus root extract (VD) maintained its hydration. Only after 90 days of study, there was a significantly decrease of the stratum corneum water content in the region treated with the vehicle formulation in malar region (Figure 3) and volar forearm (Figure 4).

\section{TEWL}

The application of the formulation containing the active ingredient significantly decreased TEWL after 45 and 90 days of treatment on the volar forearm and the tes do estudo (Figura 2). As outras regiões e parâmetros avaliados não apresentaram diferenças significativas.

\section{Efeitos em longo prazo}

\section{Teor de água do estrato córneo}

Os resultados deste estudo mostraram que o teor de água do estrato córneo da região tratada com o veículo diminui significativamente após 45 e 90 dias após a aplicação das formulações. Enquanto isso, a região tratada com a formulação contendo extracto de raiz de $\mathrm{Ci}$ chorium intybus(VD) manteve sua hidratação. Somente após 90 dias de estudo, houve diminuição significativa do teor de água do estrato córneo na região tratada com a formulação veículo na região malar (Figura 3) e na parte interna do antebraço (Figura 4).

\section{Perda Transepidermal de Água}

A aplicação da formulação que contém o ingrediente ativo diminuiu significativamente a pedra transepidermal de água após 45 e 90 dias de tratamento na parte
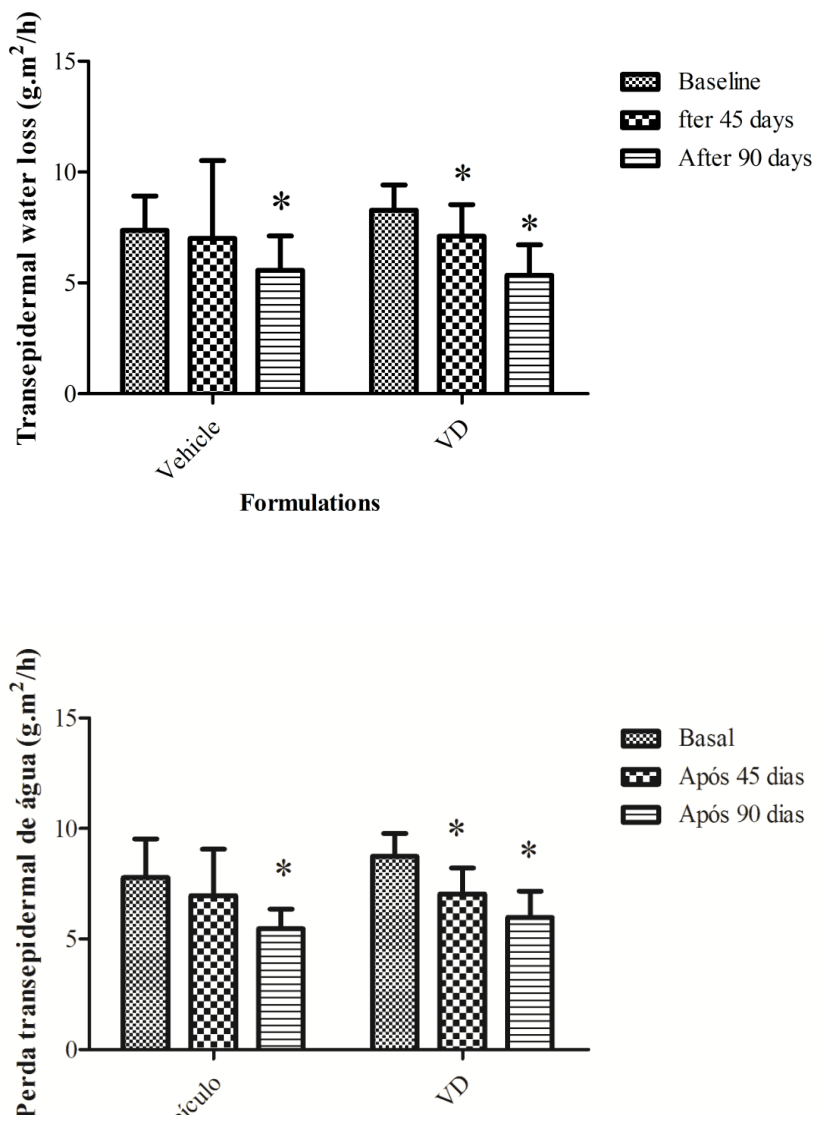

Figure 5/ Figura 5 - Transepridermal water loss (means + SD) for each treatment applied on the volar forearm. Data was obtained by Tewameter measurements after 0,45 and 90 days of daily application $(\mathrm{n}=$ 15). Control - skin without formulation, Vehicle - formulation without VD and VD - formulation containing $3 \%$ of Cichorium intybus extract.* Indicates statistically different relative to the baseline $(\mathrm{p} \leq 0.05)$. Perda transepidermal de água (média + DP) para cada tratamento aplicado na região interna do antebraço. Os dados foram obtidos por medidas de Teameter após 0,45 e 90 dias de aplicação $(n=15)$. Controlo - pele sem formulação, Veículo - formulação sem VD e VD - formulacão contendo 3\% de extracto de Cichorium intybus.

* Médias estatisticamente diferente comparando com medidas basais e após 2 horas de aplicação $(\mathrm{p} \leq 0,05)$. 
vehicle only reduced TEWL after 90 days of study (Figure 5). The other regions evaluated show no significant differences.

\section{Skin microrelief}

Skin roughness (SER) is a parameter that calculates the gray levels above a threshold in comparison with the entire image. It reflects the 'asperity' of the skin.

After treatment with the formulation containing VD, the SER parameter was not changed. However, there
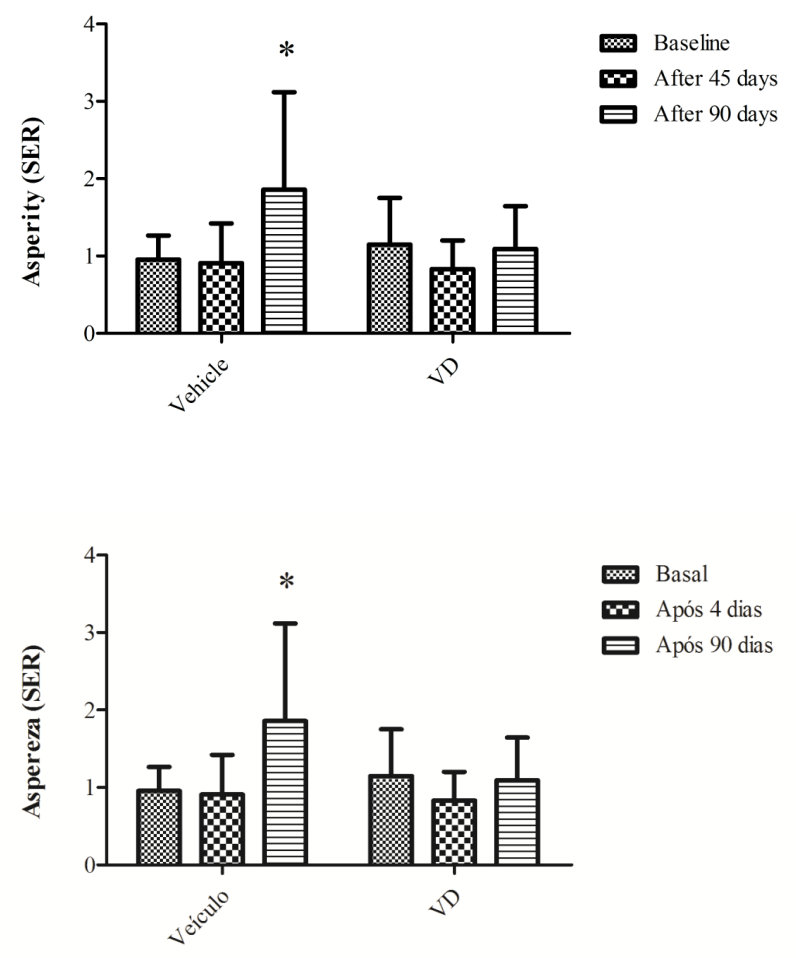

Figure 6/ Figura 6 - Asperity (means + SD) for each treatment applied on the malar region of the face. Data was obtained by Visioscan measurements after 0,45 and 90 days of daily application $(n=15)$. Control - skin without

formulation, Vehicle - formulation without VD and VD - formulation containing 3\% of Cichorium intybus extract.* Indicates statistically different relative to the baseline $(\mathrm{p} \leq 0.05)$.

Figura 6.Aspereza (média $+\mathrm{DP}$ ) para cada tratamento aplicado na região malar da cara. Os dados foram obtidos por medidas de Visioscan após 0,45 e 90 dias de aplicação $(\mathrm{n}=15)$. Controlo - pele sem formulação, Veículo - formulação sem VD e VD - formulação contendo 3\% de extracto de Cichorium intybus. * Médias estatisticamente diferente comparando com medidas basais e após 2 horas de aplicação $(\mathrm{p} \leq 0,05)$. anterior do antebraço e o veículo reduziu essa perda após 90 dias de estudo (Figura 5). As outras regiões avaliadas não apresentam diferenças significativas.

\section{Microrrelevo da pele}

A rugosidade da pele (SER) é um parâmetro que calcula os níveis de cinza acima do limiar em comparação com a imagem inteira. Isso reflete a "aspereza" da pele.

Após o tratamento com a formulação contendo VD, o parâmetro SER não foi alterado. No entanto, houve um
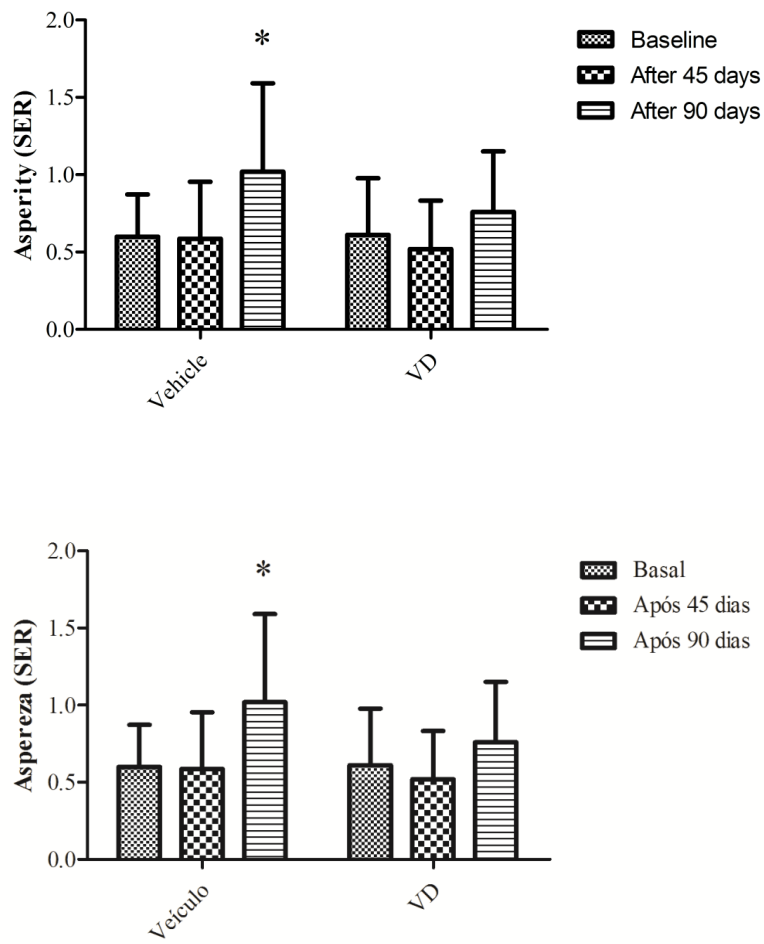

Figure 7/ Figura 7 - Asperity (means + SD) for each treatment applied on the volar arm. Data was obtained by Visioscan measurements after 0,45 and 90 days of daily application $(n=15)$. Control - skin without formulation, Vehicle - formulation without VD and VD - formulation containing $3 \%$ of Cichorium intybus extract.* Indicatesstatistically different relativeto the baseline $(\mathrm{p} \leq 0.05)$.

Aspereza (média + DP) para cada tratamento aplicado na região interna do antebraço. Os dados foram obtidos por medidas de Visioscan após 0, 45 e 90 dias de aplicação $(n=15)$. Controlo - pele sem formulação, Veículo - formulação sem VD e VD - formulação contendo 3\% de extracto de Cichorium intybus. * Médias estatisticamente diferente comparando com medidas basais e após 2 horas de aplicação $(p \leq 0,05)$. 
was a significant increment in this parameter after 90 days of treatment with the vehicle formulation in malar region (Figure 6) and arm (Figure 7).

\section{Sensory analysis}

The formulation containing VD as well as the vehicle
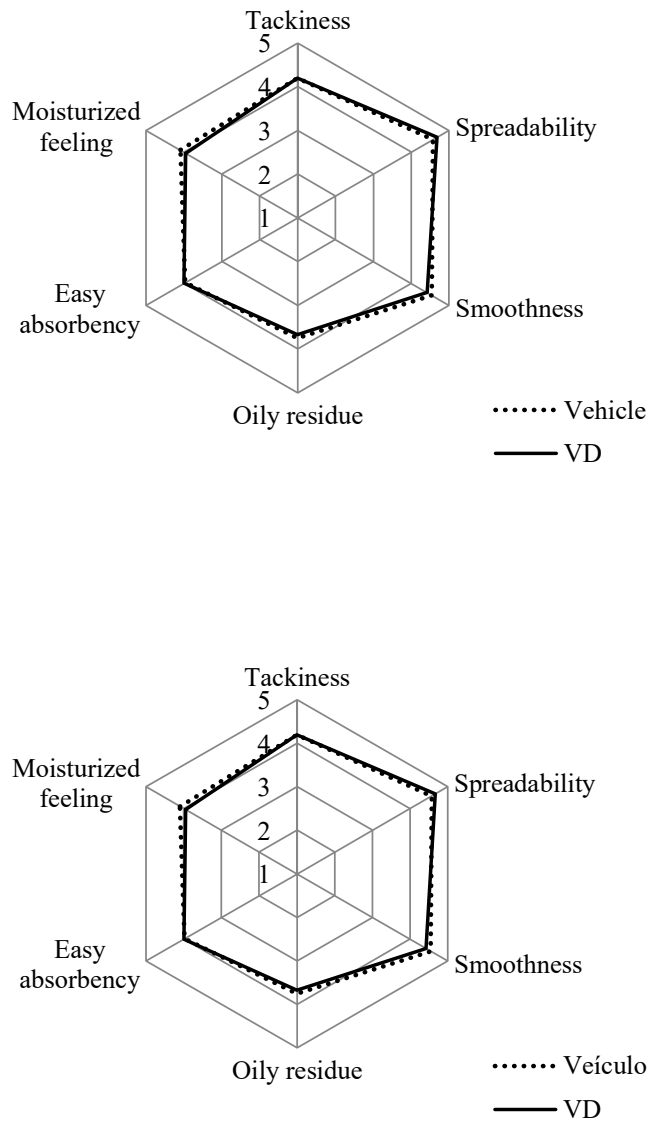

Figure 8/ Figura 8 - Average of the scores attributed for each evaluated sensory property by 40 volunteers during

application. Vehicle - formulation without VD and VD - formulation containing $3 \%$ of Cichorium intybus extract.

Média das notas atribuídas para cada propiedade sensorial de 40 voluntários durante a aplicação. Veículo - formulação sem VD e VD - formulaçã̃o contendo 3\% de extracto de Cichorium intybus. aumento significativo neste parâmetro após 90 dias de tratamento com a formulação do veículo na região malar (Figura 6) e no braço (Figura 7).

\section{Análise sensorial}

A formulação contendo VD, assim como o veículo,
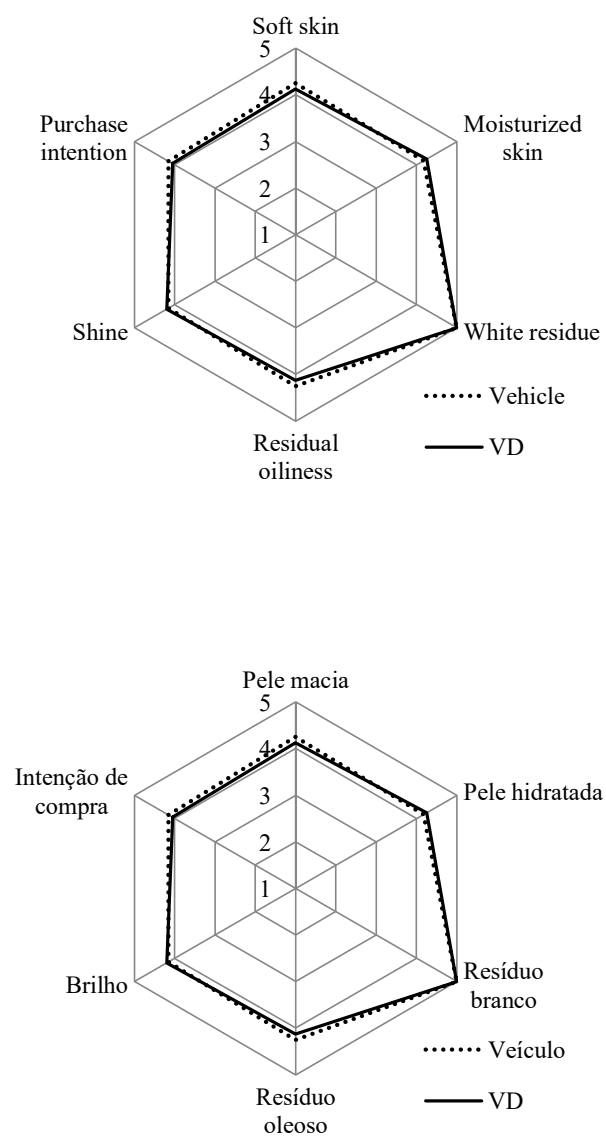

Figure 9/ Figura 9 - Average of the scores attributed for each evaluated sensory property by 40 volunteers after five minutes of application of the formulations. Vehicle - formulation without VD and VD - formulation containing $3 \%$ of Cichorium intybus extract.

Média das notas atribuídas para cada propiedade sensorial de 40voluntários após 5 minutos da aplicação das formulações. Veículo - formulação sem VD e VD - formulação contendo 3\% de extracto de Cichorium intybus. 
showed the high average scores for all the sensory parameters evaluated during application (Figure8) and 5 minutes after application (Figure 9).

\section{Discussion}

The effects after a single application and daily application of the formulation with a vitamin D-like active ingredient for 45 and 90 days were evaluated using biophysical and skin imaging techniques.

Skin is a multifunctional organ, serving as important defense functions against external insults to the body. In winter the combination of harsh cleanser use, cold temperatures, and low humidity make the conditions ideal for dry skin. Visible skin dryness has been found to correlate positively with lack of surface hydration using conductance and stratum corneum water content measurements ${ }^{(1)}$.

In attempt to reduce the effects of low humidity on skin, oil-based cream and formulations mainly containing vegetable oils have been commonly used ${ }^{(13)}$.In this study, an effective formulation that may act on vitamin $\mathrm{D}$ receptors was proposed and tested, appearing to regulate skin differentiation and hydration.

The whole study was carried out in autumn and winter seasons when the weather in Ribeirão Preto (Brazil) is very dry with the air humidity around $20 \%$. Even though this dry weather, the formulation containing the vitamin D-like active ingredient acted to improve of dry skin conditions since it was able to keep skin hydration and skin barrier when compared to the vehicle. Stratum corneum (SC) is formed by corneocytes imbedded in lipid lamellar matrix. The water content of the stratum corneum and surface lipids such as ceramides and cholesterol form a balance, which is very important for the function and appearance of the skin. Lipid bilayers and water form an intercellular multilamellar liquid crystalline gel structure that is involved in preventing transepidermal water loss ${ }^{(14)}$.

A normal skin barrier is the main aspect of skin homeostasis and regeneration. Impaired skin barrier function allows for increased water loss from the body and increased penetration of harmful substances from the environment, which favor the development of sensitization and immune responses of $\operatorname{skin}^{(15)}$.

The studied formulation containing the active ingredient significantly decreased TEWL after 45 days and 90 days of treatment on the forearm. Meanwhile, the vehicle only reduced TEWL after 90 days of study. The volar forearm showed the lowest baseline values comparing to the arm and the malar region.

As the forearm was the most dry skin region evaluated apresentaram altas notas para todos os parâmetros sensoriais avaliados durante a aplicação (Figura 8) e 5 minutos após a aplicação (Figura 9).

\section{Discussão}

Os efeitos após uma única aplicação e a aplicação diária da formulação com ingrediente ativo com Vitamina D-like durante 90 dias foram avaliados utilizando técnicas de biofísica e de imagem da pele.

A pele é um órgão multifuncional, servindo importantes funções de defesa contra danos externos ao corpo. No inverno, a combinação do uso de produtos de limpeza agressivos, temperaturas frias e humidade baixa tornam as condições ideais para a pele seca. O ressecamento superficial visível da pele foi correlacionada positivamente com a falta de hidratação superficial usando medidas de condutância e conteúdo de água do estrato córneo ${ }^{(1)}$.

$\mathrm{Na}$ tentativa de reduzir os efeitos da baixa umidade na pele, tem sido usados cremes à base de óleo e formulações principalmente com óleos vegetais ${ }^{(132)}$. Neste estudo, foi proposto e testada uma formulação efetiva que pode atuar em receptores de Vitamina $\mathrm{D}$ e, regula a diferenciação e a hidratação da pele.

Todo o estudo foi conduzido nas estações de outono e inverno quando em Ribeirão Preto (Brasil) o clima é muito seco com umidade do ar em torno de $20 \%$. Mesmo com este clima seco, a formulação contendo ingrediente ativo de Vitamina D atuou na melhora da condição de pele seca, uma vez que foi capaz de manter a hidratação da pele e a barreira quando comparado ao veículo.

O estrato córneo (EC) é formado por corneócitos embutidos na matriz lamelar lipídica. O teor de água do estrato córneo e lipídios de superfície como ceramidas e colesterol formam um equilíbrio, o que é muito importante para a função e aparência da pele. As bicamadas lipídicas e a água formam uma estrutura de gel cristalino líquido multilamelarintercelular que está envolvida na prevenção da perda de água transepidermal ${ }^{(14)}$.

A barreira normal da pele é o principal aspecto da homeostase e regeneração da pele. A função barreira cutânea prejudicada permite uma maior perda de água do corpo e uma maior penetração de substâncias prejudiciais do meio ambiente, que favorecem o desenvolvimento de sensibilização e respostas imunes da pele ${ }^{(15)}$. A formulação estudada contendo o ingrediente ativo diminuiu significativamente o PTEA após 45 dias e 90 dias de tratamento no antebraço. Enquanto isso, o veículo reduziu o PTEA após 90 dias de estudo. A parte interna do antebraço mostrou os valores basais mais 
in this study, this region presented the most pronounced effects.

Dry and rough skin is characterized for less cohesion between corneocytes and increased desquamation. In this study, the microrelief parameters of skin treated with the formulation containing VD showed lower mean roughness (SER) values, which remained unchanged throughout the treatment. However, a continued increase in SER values was found for the vehicle.

The present findings thus support a previous study of our group. Maia Campos et al. ${ }^{(6)}$ used SDS solution to reduce the natural level of skin hydration. After 28 days of treatment with Cichorium intybus root extract based formulation, the TEWL was decreased and the skin microrelief was improved.

The addition of Cichorium intybus root extract was well accepted by the subjects of the study. Either formulations containing or not $3 \%$ of this active ingredient showed high and similar scores in sensory evaluation. Calixto and Maia Campos ${ }^{(16)}$ also found great acceptance for a cosmetic formulation containing Cichorium intybus root extract. The same authors also found a higher (physical) consistency for a cosmetic formulation with $1 \%$ of Cichorium intybus root extract. The authors attributed this higher consistency to the inulin, a polysaccharide found in the extract that can affect the physical properties of the formulations.

In the current study, a higher concentration of the Cichorium intybus root extract was used. However, it did not influence the score of sensory evaluation. Although previous study had showed a higher cohesiveness, consistency, firmness and index of viscosity of the formulation containing $\mathrm{VD}^{(17)}$, these did not influence the consumer perception .

In conclusion, Cichorium intybus root extract - "vitamin D like" - is an effective active ingredient to use in cosmetic formulations to avoid skin dryness. In addition, the addition of this extract kept the sensory properties of the studied cosmetic formulation.

\section{Acknowledgments}

The authors thank FAPESP (Fundação de Apoio à Pesquisa do Estado de São Paulo) for fellowship granted to Dr. Tais A.L. Wagemaker (FAPESP 2014/11947-1) and CNPq (Conselho Nacional de Desenvolvimento Científico e Tecnológico) for a scholarshipto Thaís Righi Paseto. baixos comparados ao braço e à região malar. Como o antebraço foi a região da pele mais seca avaliada neste estudo, esta região apresentou efeitos mais pronunciados.

Pele seca e áspera é caracterizada por menor coesão entre corneócitos e descamação aumentada. Neste estudo, os parâmetros do microrrelevo mostraram valores de baixa rugosidade média (SER) permanecendo inalterados ao longo do tratamento com a formulação contendo VD. No entanto, um aumento contínuo nos valores de SER foi encontrado para o veículo.

Os resultados presentes apoiam um estudo prévio do nosso grupo. Maia Campos et al. ${ }^{(6)}$ usaram a solução SDS para reduzir o nível natural de hidratação da pele. Após 28 dias de tratamento com a formulação à base de extracto de raiz de Cichorium intybus(chicória), a PTEA diminuiu e o microrrelevo da pele foi melhorado. A adição de extracto de raiz de Cichorium intybus foi bem aceita pelos participantes do estudo. As formulações contendo $3 \%$ ou não deste ingrediente ativo apresentaram pontuações altas e similares na avaliação sensorial. Calixto e Maia Campos ${ }^{(16)}$ também encontraram grande aceitação para uma formulação cosmética adicionada do extracto de raiz de Cichorium intybus. Os mesmos autores também encontraram uma maior consistência para uma formulação cosmética com $1 \%$ de extracto de raíz de Cichorium intybus. Os autores atribuíram esta maior consistência à inulina de um polissacarídeo encontrado no extracto de chicória que pode afetar as propriedades físicas das formulações.

Neste estudo, utilizou-se uma maior concentração do extracto de raiz de Cichorium intybus. No entanto, esta não influenciou a pontuação da avaliação sensorial. Embora o estudo anterior tenha mostrado maior coesão, consistência, firmeza e índice de viscosidade da formulação adicionada de $\mathrm{VD}{ }^{(17)}$, isso não influenciou a percepção do consumidor.

Finalizando, oextracto de raíz de Cichorium intybus- "Vitamina D like" é um ingrediente ativo eficaz para aplicação em formulações cosméticas para evitar o ressecamento da pele. Além disso, a Vitamina D não alterou as propriedades sensoriais da formulação cosmética estudada.

\section{Agradecimentos}

Os autores agradecem a bolsa de estudos concedida ao Dr. Tais AL Wagemaker (FAPESP 2014 / 11947-1) e ao $\mathrm{CNPq}$ para um bolsa de estudos para Thaís Righi Paseto . 


\section{Conflict of Interest}

The authors declare that there is no financial or personal relationship that can be understood as representing a potential conflict of interest.

\section{Conflito de interesses}

O autor declara não existir qualquer relação pessoal ou financeira que possa ser entendida como representando um potencial conflito de interesses.

\section{References/ Referências}

[1] Pons-Giraud A. Dry skin in dermatology: a complex physiopathology. J Eur Acad Dermatol Venereol 2007; $21: 1-4$.

[2] Lóden M. The clinical benefit of moisturizers. J Eur Acad Dermatol Venereol 2005; 19: 672-688.

[3] Mostafa WZ, Regazy RA. Vitamin D and the skin: Focus on a complex relationship: A review. Int. J. Adv. Res2015; 6: 793-804.

[4] Bikle DD. Vitamin D metabolism and function in the skin. Mol. Cell. Endocrinol 2011; 347: 80-89.

[5] Russel M. Assessing the Relationship between Vitamin D3 and Stratum Corneum Hydration for the Treatment of Xerotic Skin. Nutrients 2012; 4: 12131218.

[6]Maia Campos PM, Mercurio DG, Melo MO, Closs-Gontier B. Cichorium intybus root extract: A "Vitamin D-like" active ingredient to improve skin barrier function. J Dermatolog Treat 2017; 28: 78-8.

[7] Xie Z, Komuves L, Yu QC, Elalieh H, Ng DC, Leary C, et al. Lack of the Vitamin D receptor is associated with reduced epidermal differentiation and hair follicle growth. J Invest Dermatol 2002; 118:11-6.

[8] Santoro MIRM, Maia Campos PMBG.Determining vitamins A, D3 and E in creams: High Performance Liquid Chromatography. Cosmetic \& Toiletries 1993; 108(6): 71-74.

[9] Silab. Enginering natural active ingredients.VederineVR Technical Information BriveCedex, France; 2012.

[10] Nóbrega AT, Wagemaker TAL, Maia Campos PMBG. Antioxidant activity of Matricaria chamomilla L. extract and clinical efficacy of cosmetic formulations containing this extract and its isolated compounds. Biomed Biopharm Res2013; 2: 249-261.

[11] Wagemaker TAL, Rijo P, Rodrigues LM, Maia Campos PMBG, Fernandes AS, Rosado C. Integrated approach in the assessment of skin compatibility of cosmetic formulations with green coffee oil. Int J CosmetSci2015, 1-5.

[12] Marcon AFVS, Wagemaker TAL, Maia Campos PMBG. Rheology, clinical efficacy and sensorial of a silicone-based formulation containing pearl extract. Biomed Biopharm Res2014; 2: 247-255.

[13] Ananthapadmanabhan KP, Moore DJ, Subramanyan K, Misra M, Meyer F. Cleansing without compromise: the impact of cleansers on the skin barrier and the technology of mild cleansing. Dermatol Ther 2004; 17: 16-25

[14] Ishikawa J, Yoshida H, Ito S, Naoe A, Fujimura T, Kitahara T, Takema Y, Zerweck C,Grove GL. Dry skin in the winter is related to the ceramide profile in the stratum corneum and can be improved by treatment with a Eucalyptus extract. J Cosmet Dermatol 2013; 12 : 3-11.

[15] Knor T, Meholijic-Fetaovic A, Mehmedagic A. Stratum corneum hydration and skin surface pH in patients with atopic dermatitis. Acta Dermatovenerol Croat 2011; 19(4): 242-247.

[16] Calixto LS, Maia Campos PMBG. Physical Mechanical characterization of cosmetic formulations and correlation between instrumental measurements and sensorial properties: texture profile and sensorial of cosmetics formulations. Int J Cosmet Sci. 2017; 39(5): 527-534.

[17] Paseto TR, Maia Campos PMBG. Development and clinical efficacy of cosmetic formulations containing "Vitamina D Like”.In: Anais do 24o Simpósio Internacional de Iniciação Científica da USP, Ribeirão Preto, SP, Brazil 2016 